\title{
Environmental challenges of digital transformation in developing countries
}

Jacqueline Hicks

Institute of Development Studies

19 July 2021

\section{Questions}

- Is there evidence on the environmental risks and challenges for digital transformation in developing countries? Are there suggestions for how these risks and challenges can be mitigated?

\section{Contents}

1. Summary

2. ICT adoption

3. Digitally-enabled energy efficiency

4. Ride-hailing apps

5. Big data analytics

7. References

The K4D helpdesk service provides brief summaries of current research, evidence, and lessons learned. Helpdesk reports are not rigorous or systematic reviews; they are intended to provide an introduction to the most important evidence related to a research question. They draw on a rapid deskbased review of published literature and consultation with subject specialists. 


\section{Summary}

This rapid review synthesises the literature on the environmental risks of four different aspects of digital transformation in developing countries: ICT adoption, digitally-enabled energy efficiency, ride-hailing apps, and big data use. Findings that relate specifically to developing countries are:

- There are particular environmental risks associated with the production of ICT goods:

- The clearest digital-related environmental risks for developing countries are associated with informal handling of domestic and international e-waste.

- Because data centres use a lot of energy for cooling the servers that store data, those built in developing countries with warmer climates are likely to need more energy.

- There are digitally-related environmental risks where developing countries have still more room for economic growth relative to developed countries.

- There is some evidence that ICT adoption in developing countries is initially correlated with increases in $\mathrm{CO} 2$ emissions, before falling once a higher level of ICT adoption is attained.

- There is some evidence that developing countries are at a particular risk of increasing unsustainable production and consumption in response to digitallyenabled energy efficiency gains - the so-called "rebound effect." This is due to a comparatively higher level of unmet demand compared to developed countries.

- However, both these fields of research have produced large numbers of studies with highly conflicting evidence. The underlying complexity of such macro-level analyses lead to results that reflect the methodology used.

- Ride-hailing apps, as an example of platform use in the "sharing economy", produce environmental risks that are context-dependent.

- There is some anecdotal evidence that drivers in developing countries are more likely to buy or rent cars in order to work with ride-hailing apps compared with developed countries where drivers tend to be existing car owners. This means that ride-hailing apps effectively add cars to the road.

- Similar to the research on developed countries, there is evidence that ride-hailing apps reduce the use of public transport, and raise congestion and pollution. Results vary depending on context.

- Historical comparison with the technological advances of the "Green Revolution" in developing countries shows that data-driven efficiencies in agriculture will not automatically lead to less deforestation.

The overall message which runs throughout the diverse literatures and results is that it is not digital technologies that create environmental risks or opportunities, but how they are used. Efficiency gains derived from digital transformation may yet lead developing countries down existing unsustainable development paths if not accompanied by careful, context-dependent policy. For policy-makers seeking to mitigate environmental risks, this means putting the context of digital use at the centre of analysis rather than the technologies themselves.

Definitions: The OECD defines digital transformation as the economic and societal effects of digitisation (where information is converted into a machine-readable format) and digitalisation (where the use of digital technologies result in new or changed activities) (OECD, 2019). 
However, the research literature covers more specific aspects of digital transformation. In practice, this report defines digital transformation as: ICT adoption, digitally-enabled energy efficiency, ride-hailing apps, and big data use. These topics were chosen after an initial scoping review of available literature, and because they exemplify a range of the different types of potential digital effects mentioned at the top of p.6 of this report. However, it should be noted that many other potential research directions could be taken to answer this report's question.

Evidence Base: The literature on the environmental risks of digital transformation is huge and conflicting. This is problematic because it could be easy to cherry pick preferred research results. Several studies noted that there is less research on developing countries than developed countries, but the evidence base is still large. As an evidence review, this report focused on the academic literature, but there is also a large grey literature. Some of the literature has a gender aspect, not covered in this report.

\section{Environmental risks associated with ICT adoption}

The positive and negative environmental impacts of information and communication technologies (ICTs) are widely debated (Higón et al, 2017).

\section{The environmental risks of ICT adoption for developing countries partly depends on their level of involvement in the manufacturing and recycling of ICT goods.}

There is general agreement in the literature that ICT contributes to increasing levels of $\mathrm{CO} 2$ emissions through the production of ICT machinery and devices, energy consumption, and recycling of electronic waste. Different developing countries therefore have different environmental risk levels depending on their level of involvement in the manufacturing and recycling of ICT goods, the type of energy used in the manufacturing process, and the procedures used in handling e-waste (Higon et al, 2017; Ozcan and Aspergis, 2018; Avom et al, 2020).

This rapid review was unable to find statistics on the global production of ICT goods. Figure 1 below shows the latest available figures for ICT goods exports by value, but this does not include ICT goods produced for domestic consumption. 


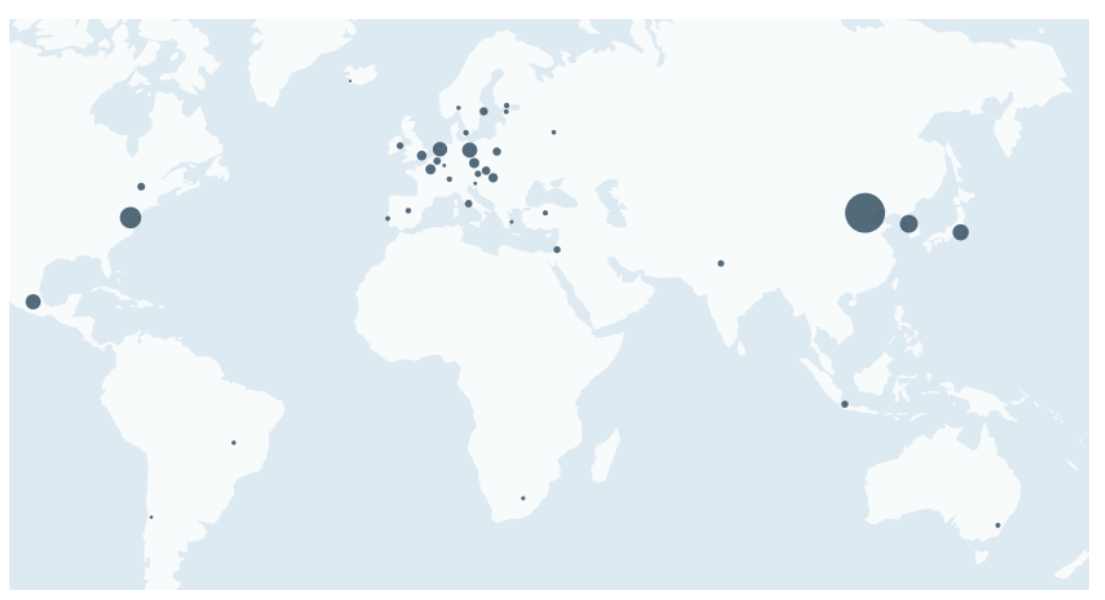

Source: OECD (2021), ICT goods exports, reproduced with permission.

Statistics on the flows of e-waste around the world are currently "insufficient for a comprehensive analysis" (Forti et al, 2020, p.55). Baldé et al. (2017) estimate that $76 \%$ of the whereabouts of e-waste are unknown, but it is widely agreed that in most developing countries "the e-waste management infrastructure is not yet fully developed or, in some cases, is entirely absent. Hence, e-waste is managed mostly by the informal sector" (Forti et al, 2020, p.14).

A 2016 study by Basel Action Network (Hopson \& Pucket, 2016) placed 205 different GPS tracking devices inside old printers, LCD, and CRT monitors, delivered them to US charities, retailers and recyclers, then followed their signals to their endpoints across the globe. The results showed that $34 \%$ of the 205 deployments moved offshore, with $31 \%$ of the total going to developing countries. Of those, $87 \%$ moved to Asia, $3 \%$ to Africa, $1 \%$ to the Middle East, and $1 \%$ to the Latin America/Caribbean region.

Different countries therefore experience different levels of environmental risk associated with receiving e-waste. They also produce starkly different levels of their own domestic ewaste, and deal with it in more or less responsible ways. The Global E-waste Statistics Partnership (GESP) collects information on the e-waste generated per capita in countries around the world in addition to details on relevant national e-waste legislation and enforcement.

International flows of e-waste are also subject to rapid change. For example, one report notes "the rapid shift of processing operations from China to Southeast Asian countries such as Thailand, Malaysia, and Vietnam as a consequence of China's import ban on waste in effect since 2018" (Forti et al, 2020, p.55).

There are many different international initiatives involved in mitigating the environmental risks associated with e-waste. These include efforts to harmonise the collection of e-waste statistics by providing training to statistics agencies in developing countries (Forti et al, 2020, p.44), to schemes in developed countries to force producers of ICT goods to take more responsibility for potential e-waste (Butler, 2021), to supporting the development of e-waste programmes around the world (Ambrosi, 2018). 


\section{Many studies try to quantify the relation between ICT adoption and CO2 emissions in developing countries, with unhelpfully conflicting results.}

This is a popular research question, given the availability of data on CO2 emissions and ICT adoption (measured by mobile phone and internet penetration rates). It is also a complex question, given the expectation that the environmental risks detailed above could be offset by the use of ICT in smarter cities, transportation systems, electrical grids, industrial processes, and energy saving gains (Higon et al, 2017). A subset of the many studies published on this topic cover developing countries or non-Western regions. Below is just a small selection of this subset.

Some studies show that ICT adoption is correlated with a reduction in $\mathrm{CO} 2$ emissions. Ozcan and Aspergis (2018) investigate the effect of ICT on CO2 emissions in 20 emerging economies from 1990 to 2015. The empirical results show that internet usage significantly reduces CO2 emissions. Lu (2018) investigates the effects of ICT, energy consumption, economic growth, and financial development on $\mathrm{CO} 2$ emissions in 12 Asian countries from 1993-2013, concluding that ICT reduces CO2 emissions. Danish (2019) analyses the relationship between ICT, real income, and $\mathrm{CO} 2$ emissions in 59 countries along the Belt and Road $^{1}$ from 1990 to 2016, concluding that ICT mitigates the level of CO2 emissions.

Other studies show that ICT adoption is correlated with an increase in CO2 emissions. Lee and Brahmasrene (2014) examine the relationships among ICT, CO2 emissions and economic growth in nine Southeast Asian countries from 1991-2009. They find that ICT adoption helps generate a significant increase in both economic growth and $\mathrm{CO} 2$ emissions.

Other studies suggest that the effect of ICT on environmental quality depends on countries' development level. Higón et al. examined the relationships among economic growth, ICT, and CO2 emissions in 116 developing countries and 26 developed countries from 1995 to 2010. The authors find that both $\mathrm{CO} 2$ emissions in both developed and developing countries rise and then fall once a higher level of ICT adoption is attained. However, they also note that higher levels of income per capita are associated with higher CO2 emissions. Danish et al (2018, p.22857) use data on eleven "emerging countries" from 1990 to 2015 to conclude that "ICT, financial development and economic growth worsen the environmental quality", but that ICT and economic growth provide a "moderating effect."

Avom et al (2020) speculate that these mixed findings can be explained by differences in the econometric technique used, the time frame and the sample of countries in the study.

\footnotetext{
${ }^{1}$ The Belt and Road initiative is a Chinese government strategy to connect Asia with Africa and Europe via land and maritime networks with the aim of improving regional integration, increasing trade and stimulating economic growth. It covers around 140 countries.
} 


\section{In the absence of a settled evidence base, the environmental risk of ICT adoption can be characterised as depending on the relative importance of three different effects.}

1. The use effect: The degree to which a country produces ICT machinery and devices, and engages in recycling of electronic waste, as already noted above. This effect will have more impact in countries that engage in ICT production and receive e-waste (Shabani et al, 2019).

2. The substitution effect: The degree to which ICT adoption in a country re-organises production processes. This includes replacing physical goods with virtual goods (e.g. ebooks instead of print books), using ICT to reduce the need for physical presence (e.g. ebanking or virtual meetings), and intelligent transportation systems. This effect will have most impact in countries that have large $\mathrm{CO} 2$ emissions in services and transportation sectors (Shabani et al, 2019).

3. The costing effect: The degree to which demand for other goods and services increase as a result of lower prices brought about by ICT adoption. This effect will have most impact on countries that have active agricultural, industrial, services, and transportation sectors (Shabani et al, 2019).

\section{Environmental risks of energy-efficiency in developing countries}

\section{Developing countries are thought to be particularly at risk of increasing consumption or energy levels as a result of efficiency gains from the use of digital technologies.}

Known as the "rebound effect" in the literature, this is where "improvements in energy conversion technologies would contribute to increasing economy-wide energy demand over and above the initial level-a phenomenon that is also termed backfire." (Santarius et al, 2020, p.6). Rebound effects can also have wider application on consumer demand and production where "an improvement in energy efficiency simultaneously increases consumers' real disposable income and expands production possibilities of firms" (Kipouros, 2017, p.56).

There is a large literature measuring actual rebound effects and estimating future ones. Brockway et al (2021) reviewed 33 studies, finding that more than two-thirds of the studies found rebound effects larger than $50 \%$. Six found rebound effects of $100 \%$ or more, implying that in some instances the energy savings may be eliminated altogether. They also note that the studies varied widely in terms of methods used and types of improvement investigated, and their results were often sensitive to uncertain assumptions. Levels of rebound effects are therefore difficult to prove on aggregate.

Developing countries are expected to have higher rebound effects because "demand is generally less sated, as incomes and consumption per capita are lower” (Deloitte, 2020, p. 4), and there is "unmet demand for energy services" (Van den Bergh, 2010, p.50). However, evidence to support this position is just as contested as the general literature, possibly more so due to there being limited evidence from developing countries. A very recent review of 40 years 
of research on energy efficiency notes the need for more research in developing countries (Saunders et al, 2021).

One report reviews 163 studies on the rebound effects to discover the impact in developing countries in particular (ECA, 2014). It finds overall that the literature estimates rebound effects to be larger for developing countries than developed ones, particularly for residential energy purposes, but notes the high degree of uncertainty in the figures.

\section{The risks of increased consumption following increased digital technology-driven energy efficiency is highly contingent on context.}

For example, one study on India shows different levels of rebound effects for residential lighting, industry, and transport (Roy, 2000). Another study looks at the rebound effects on urban passenger transport in China, showing different rebound levels in different provinces resulting from differences in economic development, and related differences in consumers' behaviour, especially in the behaviour of "marginal consumers" - those who cannot afford the high costs of private transport before the cost savings offered by the energy efficiency improvement come into being (Chen et al, 2019).

\section{'Rebound policies' are recommended as mitigation for risks of increased energy consumption, but may harm those suffering energy poverty in developing countries.}

While rebound policies need to be context-specific, one scholar (Van den Bergh, 2010) suggests some possible elements including:

- Information provision and "moral suasion"

- Command-and-control (direct/physical regulation or technological/emission standards)

- Market-based instruments or price regulation (taxes, levies)

- Subsidizing energy conservation

- Tradable permits (i.e. an overall ceiling combined with a price mechanism)

However, others recognise that "in developing countries, rebound-suppressing policies cannot help achieve affordable access to energy (Strategic Development Goal SDG 7 - 'Affordable and Clean Energy') faster, so rebound-suppressing policies can disproportionately harm consumers [experiencing] energy poverty" (Chakravarty et al, 2013 in Saunders et al, 2021).

\section{Ride-hailing apps in developing countries}

Some researchers approach the issue of potential environmental risks and opportunities of digital transformation by asking whether ride-hailing apps increase or decrease transport-related pollution in developing countries. This is in response to the claims made by some mobile phone industry bodies (GSMA, 2019) or ride-hailing companies (Uber, 2020) that using these apps can support reductions in $\mathrm{CO} 2$ emissions. Yuana et al (2019) note that ride-hailing companies more frequently frame their service as environmentally sustainable in the West than in developing 
countries, where companies are more likely to frame them as a solution to insufficient public transport.

Note that this section uses the term 'ride-hailing app' not 'ride-sharing app', meaning the use of a smartphone application to order a customised ride online. The terms 'ride-hailing' and 'ridesharing' are often used interchangeably in the literature, but this section uses the former to distinguish it from car-pooling type trips with several passengers, or from schemes which promote fractional car ownership or co-leasing.

\section{There is some evidence that ride-hailing apps add cars to the road in developing countries, but results are mixed.}

Several reports note that ride-hailing apps operate differently in developing countries in terms of car ownership. In developed countries, existing car owners tend to register to become drivers on the platforms. In developing countries, many drivers either buy a new car to become drivers with the app, or rent cars from a middle-man who has bought the car especially for the purpose (Eisenmeier, 2018; Guo et al (2018); Gong \& Song, 2017).

Eisenmeier (2018) reports from an interview with an Uber executive in Mexico City that 60 per cent of the drivers do not own the car they drive, effectively meaning that the apps encourage people to acquire a car who otherwise might not buy one.

Guo et al (2018) investigate whether the adoption of Chinese ride-hailing app, Didi Chuxing, increases or decreases new car sales shortly after the platform's entry into 51 cities in China. They find that "the initial entry of a dominant ride-hailing company like Didi Chuxing positively impacts new car sales in the short run," but speculate that this is likely to be transitory (p.133).

By contrast, Vanderschuren \& Baufeldt (2018, p.607) found that in Cape Town "there is a growing amount of people that omit using their own vehicle, but rather use ride-share services."

A different study (Zhong et al, 2020) analyzes the impact of ride-hailing services on the use of private cars with data from 109 cities in China from 2010 to 2016. It shows that the use of private cars initially reduced substantially, then weakened over time. Results show a more significant reduction (15\%) in cities located in the east of the country (which have a higher economic level) compared to the West where data showed no significant impact. The authors conclude that the influence of ride-hailing services on private car use in urban areas is heterogeneous across time and cities.

Agarwal et al (2021) study how ride-hailing unavailability affects congestion in three Indian cities by using real-time traffic data during periods when drivers of the largest ride-hailing apps were on strike. They find a discernible drop in travel time during periods of ride-hailing unavailability, concluding that ride-hailing vehicles are contributing significantly to congestion in the cities studied.

Recent research on this topic has begun to investigate more in depth the different conditions under which ride-hailing apps help or hinder traffic congestion. For example, Li et al (2021) conclude that use of the apps increases traffic congestion in "compact areas", but decreases it in "sprawling urban areas" in the US. This rapid review did not find similar analyses for developing countries within this large and dynamic research field. 


\section{Some research suggests that ride-hailing apps can add to pollution and reduce public transport use in developing countries.}

One study (Barnes et al, 2020) examines the impact of the introduction of ride-hailing app Didi Chuxing on pollution levels (measured by PM2.5 levels) in China. They find that the apps' introduction provides an initial drop in pollution levels, then leads to an overall increase. The authors speculate that this may be due to factors such as an increase in trip generation, changes in travel patterns, and a substitution of more sustainable modes of transportation like public transport.

Another study on China used GPS data covering around 7 thousand taxis with 0.3 million trips and 23 thousand Didi (ride-hailing) vehicles in Chengdu, China. It finds that fuel consumption and carbon monoxide, nitrogen oxides, hydrocarbon emissions per passenger-on kilometer of taxi trips are around 1.36, 1.45, 1.36 and 1.44 times that of Didi trips. In other words, Didi trips produce less pollution that taxis (Sui et al, 2019).

An indirect way to consider the effect of ride-hailing apps on pollution is to survey users about what form of transport they substituted in their last ride-hailing app journey. If they report that they would have taken public transport instead of the app, this indicates that it likely leads to increased pollution as it is effectively adding a car journey. Tirachini \& del Río $(2019$, p.53) note that "The effect of ride-hailing on traffic critically depends on the transport mode that the former has replaced, and whether car ownership decisions are influenced by the use of ride-hailing in the long run. The authors detail several studies on this topic in their literature review, summarised below in Table One.

Table 1: Substitution Effects of Ride-hailing (last journey made) in several developing and developed countries

\begin{tabular}{lllll}
\hline City/Country & $\begin{array}{l}\text { App use } \\
\text { substituted a } \\
\text { taxi journey }\end{array}$ & $\begin{array}{l}\text { App use } \\
\text { substituted } \\
\text { public } \\
\text { transport }\end{array}$ & $\begin{array}{l}\text { App use } \\
\text { substituted a } \\
\text { private car } \\
\text { journey }\end{array}$ & Reference \\
\hline $\begin{array}{l}\text { Santiago de Chile/ } \\
\text { Chile }\end{array}$ & $39.2 \%$ & $37.6 \%$ & $15.9 \%$ & $\begin{array}{l}\text { Tirachini \& del } \\
\text { Río (2019) }\end{array}$ \\
\hline $\begin{array}{l}\text { Several Brazilian } \\
\text { cities }\end{array}$ & $50 \%$ & $30 \%$ & $18 \%$ & $\begin{array}{l}\text { de Souza Silva } \\
\text { et al. (2018) }\end{array}$ \\
\hline $\begin{array}{l}\text { Ten Chinese } \\
\text { cities }\end{array}$ & $35.1 \%$ & $37.4 \%$ & $17.3 \%$ & $\begin{array}{l}\text { Tang et al. } \\
(2019)\end{array}$ \\
\hline $\begin{array}{l}\text { Denver/ USA } \\
\text { Beston/USA }\end{array}$ & $9.6 \%$ & $22.2 \%$ & $19 \%$ & $\begin{array}{l}\text { Henao and } \\
\text { Marshall (2018) }\end{array}$ \\
\hline California & $45 \%$ & $42 \%$ & $19 \%$ & $\begin{array}{l}\text { Gehrke et al. } \\
(2018)\end{array}$ \\
\hline
\end{tabular}

Source: Based on information in Tirachini \& del Río (2019) 


\section{One way to mitigate environmental risks associated with ride- hailing apps is to require companies to electrify the miles driven by their fleets.}

Industry research recognises that one reason ride-hailing apps could help reduce pollution is because "cars hailed are statistically more energy efficient than personal cars" (GSMA, 2019). A report by the Union of Concerned Scientists (Anair et al, 2020) found that ride-hailing trips in the USA are $69 \%$ more polluting than the trips they replace and a non-pooled Uber or Lyft ride is $47 \%$ more polluting than a private car trip. In May 2021, California passed a first-of-its kind requirement that ride-hailing companies electrify their fleet (Irvin, 2021).

One report (Slowik et al, 2019) assesses the electrification commitments of five major ride-hailing companies including Didi, Ola and Grab, whose primary markets are based in China, India and Southeast Asia respectively. Based on press releases, interviews and media stories, the report finds that Didi has the largest electric vehicle fleet, with $1.3 \%$ of total vehicles, or 260,00 in total. The report shows that there is a large capacity for all of the companies to increase electric vehicle share.

\section{Other mitigation policies relate to the apps' integration with public transport, and are context-specific.}

- Eisenmeier (2018) notes that governments could regulate ride-sharing platforms to ensure that they complement existing public transportation. The exact nature of the regulation would depend on the existing structure of the public transport market.

- Vayouphack (2020) suggests that governments in developing countries may need to limit the number of ridesharing vehicles and impose quality control to avoid lowering drivers' incomes who then try to reduce their costs by using cars that cause pollution.

- Uber's commitment to "decarbonising" its platform involves introducing an app feature where riders choose to travel in hybrids or electric vehicles, committing funds to help drivers transition to electric vehicles, and investing in a "multimodal network" to integrate public transport options into their journey planner (Uber, 2020).

- However, Vanderschuren \& Baufeldt (2018) caution that any government regulation should be mindful of the very real benefits that ride-hailing apps provide to those with limited public transport options, what they term "mobility poverty" (p.608).

\section{Big data use in developing countries}

There is a very large literature dispersed across multiple fields on the potential or actual benefits of big data analytics to help deal with environmental issues, including in developing countries. Feroz et al (2021) provide a review of around 1000 research articles on the use of artificial intelligence, big data analytics, cloud computing, and the Internet of Things (loT) on four issues: pollution control, waste management, sustainable production, and urban sustainability. Some of this literature may contain specific examples of environmental risk in developing countries as well, but it is beyond the reach of this rapid review. 


\section{The energy requirements of the data centres needed for big data analytics may be more in warmer climates.}

Notley (2019), among many others, notes that the creation, processing, storage and movement of data relies on extensive natural and finite resources including electricity, water, metals, elements and chemicals. These resources are needed to build and run data centres as well as fibre optic cables.

At present, the vast majority of data centres are located in the USA (Cloudscene, 2021). Data centres in the USA account for $2 \%$ of the USA's total energy consumption (Shehabi et al, 2016). Cooling accounts for more than $\mathbf{4 0 \%}$ of the energy consumption of data centres (Shehabi et al, 2016). The energy demands associated with cooling data centres is one reason why large tech companies tend to look for colder climates to build their data centres (Lucivero, 2019).

A new surge in data centre building is now occurring outside of the USA, causing an "uptick in the general data center cooling market [as] data centers [are] built in developing countries or regions such as Singapore and Latin America" (Gyarmathy, 2020). However, the environmental risk of increased energy use by building data centres in the warmer climates associated with developing countries could be partially offset by the use of new technologies (Masanet et al, 2020).

\section{Some research uses historical comparison to argue that big data use may lead to increased unsustainable production, or only very small gains.}

Many researchers note the potential for a "Jevons' Paradox" of big data use in manufacturing. Jevons was an economist in the nineteenth century who demonstrated how the development of more efficient steam engines increased coal production as demand and uses of these engines rose (Polimeni \& Polimeni, 2006). Dauvergne (2020, p.2) says that "Al is supercharging the technologies of modern capitalism, akin to what electricity did after the late 1800 s."

Hilty et al (2011, p.13) state that "technological efficiency alone will not produce sustainability." They quote the example of smart drink vending machines which use half the energy of a normal vending machine through several technological innovations. This meant it became cost-effective to place the machines in smaller offices, substantially raising the number of machines produced and in operation. In effect, a "green" energy-efficient machine was bad for sustainability.

Considering whether smart technologies can increase agricultural yield in developing countries so that deforestation becomes unnecessary, Ngoma et al (2018) cite research on the so-called Green Revolution. This was a period from the 1960s onwards where more technology-intensive agricultural practices were introduced to the developing world, including high yield varieties of seeds and chemical fertilizers. The authors note that subsequent research showed a reduction of just $0.6 \%$ in absolute annual forest loss as a result of the Green Revolution (Achard et al., 2014 in Ngoma et al, 2018, p.183) which was orders of magnitude lower than predicted because it "did not take account of feedback loops through prices of products, consumption demand, and landuse decisions" (Stevenson et al. 2013, 8365, in in Ngoma et al, 2018, p.183). 
This idea that potential gains and risks of using technologies depends on the wider system within which it is embedded is also apparent in an article on the use of "precision agriculture" which uses smart technologies and big data analytics to support the "agri-food system" (Flausch, 2019). Highlighting the success of a project using data analytics to reduce water and soil pollution, the article quotes a climate campaigner involved in the project as saying: "the true innovation [was] not the computer programme itself, but the collaboration between various actors."

\section{References}

Achard, F., Beuchle, R., Mayaux, P., Stibig, H., Bodart, C., Brink, A., ... Simonetti, D. (2014). Determination of tropical deforestation rates and related carbon losses from 1990 to 2010. Global Change Biology, 20(8), 2540-2554. https://doi.org/10.1111/gcb.12605

Agarwal, S., Deepa, M. \& Rahul, T. (2019).The impact of ride-hailing services on congestion: Evidence from Indian cities. Indian School of Business, http://dx.doi.org/10.2139/ssrn.3410623

Alemi, F., Circella, G., Handy, S., \& Mokhtarian, P. (2018). What influences travellers to use Uber? Exploring the factors affecting the adoption of on-demand ride services in California. Travel Behaviour and Society, 13, 88-104. https://doi.org/10.1016/j.tbs.2018.06.002

Ambrosi, V. (2018). Successful electronic waste management initiatives. ITU. https://www.itu.int/en/ITU-D/Climate-Change/Documents/2018/Successful-electronicwaste-management-initiatives.pdf

Anair, D., Martin, J., Pinto de Moura, M. \& Goldman, J. (2020). Ride-hailing's climate risks: Steering a growing industry toward a clean transportation future. Cambridge, MA: Union of Concerned Scientists. https://www.ucsusa.org/sites/default/files/2020-02/RideHailing\%27s-Climate-Risks.pdf

Avom, D., Nkengfack, H., Fotio, H. K., \& Totouom, A. (2020). ICT and environmental quality in Sub-Saharan Africa: Effects and transmission channels. Technological Forecasting and Social Change, 155, 120028. https://doi.org/10.1016/j.techfore.2020.120028

Baldé, C.P., Forti V., Gray, V., Kuehr, R., Paul, S. (2017). The global e-waste monitor-2017, United Nations University (UNU), International Telecommunication Union (ITU) \& International Solid Waste Association (ISWA), https://www.itu.int/en/ITU-D/ClimateChange/Documents/GEM\%202017/Global-E-waste\%20Monitor\%202017\%20.pdf

Barnes, S., Guo, Y., \& Borgo, R. (2020). Sharing the air: Transient impacts of ride-hailing introduction on pollution in China. Transportation Research Part D: Transport and Environment, 86, 102434. https://doi.org/10.1016/j.trd.2020.102434

Brockway, P., Sorrell, S., Semieniuk, G., Heun, M., \& Court, V. (2021). Energy efficiency and economy-wide rebound effects: A review of the evidence and its implications. Renewable and Sustainable Energy Reviews, 141, 110781. https://doi.org/10.1016/j.rser.2021.110781

Butler, S. (26 Feb, 2021). Kerbside scheme to cut electronic waste could be launched in UK, Guardian, https://www.theguardian.com/business/2021/feb/26/kerbside-scheme-collectelectronic-waste-uk 
Chakravarty, D., Dasgupta, S., \& Roy, J. (2013). Rebound effect: how much to worry? Current Opinion in Environmental Sustainability, 5(2), 216-228.

https://doi.org/10.1016/j.cosust.2013.03.001

Chen, Z., Du, H., Li, J., Southworth, F., \& Ma, S. (2019). Achieving low-carbon urban passenger transport in China: Insights from the heterogeneous rebound effect. Energy Economics, 81, 1029-1041. https://doi.org/10.1016/j.eneco.2019.06.009

Cloudscene (2021). Markets. https://discover.cloudscene.com/search/markets

Danish, K., Baloch, M., Saud, S., \& Fatima, T. (2018). The effect of ICT on CO2 emissions in emerging economies: does the level of income matters? Environmental Science and Pollution Research, 25(23), 22850-22860. https://doi.org/10.1007/s11356-018-2379-2

Danish. (2019). Effects of information and communication technology and real income on CO2 emissions: The experience of countries along Belt and Road. Telematics and Informatics, 45, 101300. https://doi.org/10.1016/j.tele.2019.101300

Dauvergne, P. (2020). Is artificial intelligence greening global supply chains? Exposing the political economy of environmental costs. Review of International Political Economy, 1-23. https://doi.org/10.1080/09692290.2020.1814381

De Souza Silva, L., de Andrade, M., \& Alves Maia, M. (2018). How does the ride-hailing systems demand affect individual transport regulation? Research in Transportation Economics, 69, 600-606. https://doi.org/10.1016/j.retrec.2018.06.010

Dehghan Shabani, Z., \& Shahnazi, R. (2019). Energy consumption, carbon dioxide emissions, information and communications technology, and gross domestic product in Iranian economic sectors: A panel causality analysis. Energy, 169, 1064-1078. https://doi.org/10.1016/j.energy.2018.11.062

Deloitte. (2020). Tech for impact: The economic and environmental impact of digital technologies in the UK. https://www2.deloitte.com/content/dam/Deloitte/uk/Documents/technologymedia-telecommunications/deloitte-uk-tech-for-impact.pdf

ECA (Economic Consulting Associates). (2014). Phase 1 final report: The rebound effect for developing countries. Evidence on Demand, UK. http://dx.doi.org/10.12774/eod_cr.march2014.eca.

Eisenmeier, S. (2018). Ride-sharing platforms in developing countries: Effects and implications in Mexico City. Pathways for Prosperity Commission Background Paper Series; no. 3. https://pathwayscommission.bsg.ox.ac.uk/sites/default/files/2019-09/ridesharing_platforms_in_developing_countries.pdf

Feroz, A., Zo, H., \& Chiravuri, A. (2021). Digital transformation and environmental sustainability: A review and research agenda. Sustainability, 13(3), 1530. https://doi.org/10.3390/su13031530

Flausch, M. (March 28, 2019). Digital innovation also creates new risks for farmers. Euractiv. https://www.euractiv.com/section/agriculture-food/news/innovation-likely-to-lead-to-morerisks-for-farmers/

Forti V., Baldé C., Kuehr R., Bel G. (2020). The global e-waste monitor 2020: Quantities, flows and the circular economy potential. United Nations University (UNU)/United Nations 
Institute for Training and Research (UNITAR) - co-hosted SCYCLE Programme, International Telecommunication Union (ITU) \& International Solid Waste Association (ISWA), https://www.itu.int/myitu/-/media/Publications/2020-Publications/EN---Global-Ewaste-Monitor-2020.pdf

Gehrke, S., Felix, A., \& Reardon, T. (2018). Fare choices, A survey of ride-hailing passengers in metro Boston. Report \#1: Metropolitan Area Planning Council (MAPC).

https://www.mapc.org/farechoices/

Gong, J., \& Song, Y. (2017). Uber might buy me a Mercedes Benz: An empirical investigation of the sharing economy and durable goods purchase. SSRN Electronic Journal.

https://doi.org/10.2139/ssrn.2971072

GSMA and Carbon Trust. (2019). The enablement effect: The impact of mobile communications technologies on carbon emission reductions, https://www.gsma.com/betterfuture/wpcontent/uploads/2019/12/GSMA_Enablement_Effect.pdf

Guo, Y., Xin, F., Barnes, S., \& Li, X. (2018). Opportunities or threats: The rise of Online Collaborative Consumption (OCC) and its impact on new car sales. Electronic Commerce Research and Applications, 29, 133-141. https://doi.org/10.1016/j.elerap.2018.04.005

Henao, A. (2017). Impacts of ridesourcing - LYFT and UBER - on transportation including VMT, mode replacement, parking and travel behavior. Ph.D. Thesis, University of Colorado, https://digital.auraria.edu/content/AA/00/00/60/55/00001/Henao_ucdenver_0765D_10823. pdf

Higón, A., Gholami, R., \& Shirazi, F. (2017). ICT and environmental sustainability: A global perspective. Telematics and Informatics, 34(4), 85-95. https://doi.org/10.1016/j.tele.2017.01.001

Hilty, L., Lohmann, W., \& Huang, E. (2011). Sustainability and ICT - An overview of the field. Notizie di Politeia, 27(104), 13-28. https://www.zora.uzh.ch/id/eprint/55640/

Hopson E., \& Pucket J. (2016). Scam recycling: e-dumping on Asia by US recyclers. Basel Action Network, USA. http://wiki.ban.org/images/1/12/ScamRecyclingReport-web.pdf

Irvin, E. (May 14, 2021). CA's Clean Miles Standard Can Benefit Environment, Ridehailing Drivers - If Companies Step Up. https://blog.ucsusa.org/elizabeth-irvin/cas-clean-milesstandard-can-benefit-environment-ridehailing-drivers-if-companies-stepup/?_ga=2.139510579.1807273714.1626369746-1150279716.1626369746

Kipouros, P. (2017). Energy efficiency and the rebound effect in developing countries. PhD Thesis, University of Surrey. https://seec.surrey.ac.uk/wpcontent/uploads/2018/10/2018ParaskevasKipurosThesis.pdf

Lee, J., \& Brahmasrene, T. (2014). ICT, CO2 emissions and economic growth: Evidence from a panel of ASEAN. Global Economic Review, 43(2), 93-109.

https://doi.org/10.1080/1226508x.2014.917803

Lu, W. (2018). The impacts of information and communication technology, energy consumption, financial development, and economic growth on carbon dioxide emissions in 12 Asian countries. Mitigation and Adaptation Strategies for Global Change, 23(8), 1351-1365. https://doi.org/10.1007/s11027-018-9787-y 
Lucivero, F. (2019). Big Data, Big Waste? A Reflection on the Environmental Sustainability of Big Data Initiatives. Science and Engineering Ethics, 26(2), 1009-1030.

https://doi.org/10.1007/s11948-019-00171-7

Masanet, E., Shehabi, A., Lei,N., Smith, S., \& Koomey, K. (2020). Recalibrating global data center energy-use estimates. Science, 367(6481), 984-986.

https://doi.org/10.1126/science.aba3758

Ngoma H, Angelsen A, Carter, S. \& Roman-Cuesta R. (2018). Climate smart agriculture: Will higher yields lead to lower deforestation? In Angelsen, A., et al (eds). Transforming REDD+: Lessons and new directions. p. 175-187. CIFOR. https://www.cifor.org/library/7045

Notley, T. (2019). The environmental costs of the global digital economy in Asia and the urgent need for better policy. Media International Australia, 173(1), 125-141. https://doi.org/10.1177/1329878x19844022

OECD. (2019). Going digital: Shaping policies, improving lives. OECD Publishing. https://doi.org/10.1787/9789264312012-en

OECD. (2021). ICT goods exports (indicator). https://doi.org/10.1787/b4d99334-en

Ozcan, B., \& Apergis, N. (2017). The impact of internet use on air pollution: Evidence from emerging countries. Environmental Science and Pollution Research, 25(5), 4174-4189. https://doi.org/10.1007/s11356-017-0825-1

Polimeni, J., \& Polimeni, R. (2006). Jevons' Paradox and the myth of technological liberation. Ecological Complexity, 3(4), 344-353. https://doi.org/10.1016/j.ecocom.2007.02.008

Roy, J. (2000). The rebound effect: some empirical evidence from India. Energy Policy, 28(6-7), 433-438 https://doi.org/10.1016/0140-6701(00)94778

Santarius, T., Pohl, J., \& Lange, S. (2020). Digitalization and the decoupling debate: Can ICT help to reduce environmental impacts while the economy keeps growing? Sustainability, 12(18), 7496. https://doi.org/10.3390/su12187496

Saunders, H., Roy, J., Azevedo, I., Chakravarty, D., Dasgupta, S., de la Rue du Can, S., ... Wei, T. (2021). Energy Efficiency: What Has Research Delivered in the Last 40 Years? Annual Review of Environment and Resources, 46(1). https://doi.org/10.1146/annurev-environ012320-084937

Shehabi, A. (2016). United States Data Center Energy Usage Report. No. LBNL-1005775. Lawrence Berkeley National Lab. (LBNL), https://www.osti.gov/servlets/purl/1372902

Slowik, P., Fedirko, L., \& Lutsey, N. (2019). Assessing ride-hailing company commitments to electrification. The International Council on Clean Transportation. https://theicct.org/publications/ridehailing-electrification-commitment

Stevenson, J., Villoria, N., Byerlee, D., Kelley, T., \& Maredia, M. (2013). Green Revolution research saved an estimated 18 to 27 million hectares from being brought into agricultural production. Proceedings of the National Academy of Sciences, 110(21), 8363-8368. https://doi.org/10.1073/pnas.1208065110 
Sui, Y., Zhang, H., Song, X., Shao, F., Yu, X., Shibasaki, R., ... Li, Y. (2019). GPS data in urban online ride-hailing: A comparative analysis on fuel consumption and emissions. Journal of Cleaner Production, 227, 495-505. https://doi.org/10.1016/j.jclepro.2019.04.159

Tang, B., Li, X., Yu, B., \& Wei, Y. (2019). How app-based ride-hailing services influence travel behavior: An empirical study from China. International Journal of Sustainable Transportation, 14(7), 554-568. https://doi.org/10.1080/15568318.2019.1584932

Tirachini, A., \& del Río, M. (2019). Ride-hailing in Santiago de Chile: Users' characterisation and effects on travel behaviour. Transport Policy, 82, 46-57. https://doi.org/10.1016/j.tranpol.2019.07.008

Uber. (2020). Climate Assessment and Performance Report, 2017-2019.

https://d1 nyezh1ys8wfo.cloudfront.net/static/PDFs/Uber_ClimateAssessmentandPerforma nceReport_10_05_2020.pdf?uclick_id=9154af4c-3f3b-4cfc-8b07-80d3e538811a

Van den Bergh, J. (2010). Energy conservation more effective with rebound policy. Environmental and Resource Economics, 48(1), 43-58. https://doi.org/10.1007/s10640010-9396-z

Vanderschuren, M., \& Baufeldt, J. (2018). Ride-sharing: A potential means to increase the quality and availability of motorised trips while discouraging private motor ownership in developing cities? Research in Transportation Economics, 69, 607-614. https://doi.org/10.1016/j.retrec.2018.03.007

Vayouphack, S. (2020). Ridesharing in Developing Countries: Perspectives from India and Thailand, Thesis, Auckland University of Technology, https://openrepository.aut.ac.nz/bitstream/handle/10292/13296/Simmavanh\%27s\%20Diss ertation.pdf? sequence=1\&isAllowed=y

Gyarmathy, K. (2020). What you should know about data center cooling technologies. vXchnge, https://www.vxchnge.com/blog/data-center-cooling-technology

Zhong, J., Lin, Y., \& Yang, S. (2020). The impact of ride-hailing services on private car use in urban areas: An examination in Chinese cities. Journal of Advanced Transportation, 1-15. https://doi.org/10.1155/2020/8831674 


\section{Suggested citation}

Hicks, J. (2021). Environmental challenges of digital transformation in developing countries. K4D Helpdesk Report. Institute of Development Studies. DOI: 10.19088/K4D.2021.107

\section{About this report}

This report is based on six days of desk-based research. The K4D research helpdesk provides rapid syntheses of a selection of recent relevant literature and international expert thinking in response to specific questions relating to international development. For any enquiries, contact helpdesk@k4d.info.

K4D services are provided by a consortium of leading organisations working in international development, led by the Institute of Development Studies (IDS), with the Education Development Trust, Itad, University of Leeds Nuffield Centre for International Health and Development, Liverpool School of Tropical Medicine (LSTM), University of Birmingham International Development Department (IDD) and the University of Manchester Humanitarian and Conflict Response Institute (HCRI).

This report was prepared for the UK Government's Foreign, Commonwealth \& Development Office (FCDO) and its partners in support of pro-poor programmes. Except where otherwise stated, it is licensed for non-commercial purposes under the terms of the Open Government Licence v3.0. K4D cannot be held responsible for errors or any consequences arising from the use of information contained in this report. Any views and opinions expressed do not necessarily reflect those of FCDO, K4D or any other contributing organisation.

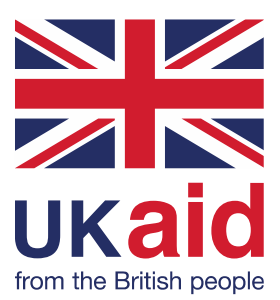

(C) Crown copyright 2021. 